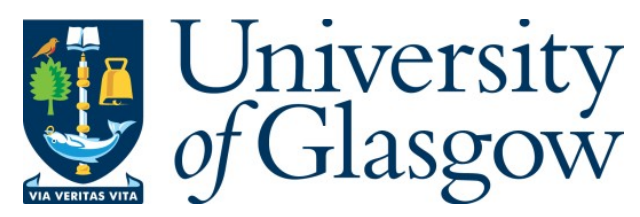

Larsen, N. K., Funder, S., Linge, H., Möller, P., Schomacker, A., Fabel, D., Xu, S., and Kjær, K. H. (2016) A Younger Dryas 1 re-advance of local glaciers in North Greenland. Quaternary Science Reviews, 147, pp. 47-58.

There may be differences between this version and the published version. You are advised to consult the publisher's version if you wish to cite from it.

http://eprints.gla.ac.uk/111461/

Deposited on: 23 October 2015

Enlighten - Research publications by members of the University of Glasgow http://eprints.gla.ac.uk 


\section{A Younger Dryas re-advance of local glaciers in North Greenland}

2

3 Nicolaj K. Larsen ${ }^{\mathrm{a}, \mathrm{b},}$, Svend Funder ${ }^{\mathrm{b}}$, Henriette Linge ${ }^{\mathrm{c}}$, Per Möller ${ }^{\mathrm{d}}$, Anders Schomacker ${ }^{\mathrm{b}}$,

4 Derek Fabel ${ }^{\mathrm{e}}$, Sheng $\mathrm{Xu}^{\mathrm{e}}$, Kurt H. Kjær ${ }^{\mathrm{b}}$

${ }^{a}$ Department of Geoscience, Aarhus University, Hфegh Guldbergs Gade 2, 8000 Aarhus C,

\section{Denmark}

${ }^{b}$ Centre for GeoGenetics, Natural History Museum of Denmark, University of Copenhagen, Øster Voldgade 5-7, 1350 Copenhagen K, Denmark

${ }^{c}$ Department of Earth Science, University of Bergen, and Bjerknes Centre for Climate

1 Research, Postbox 7803, N-5020 Bergen, Norway

$2{ }^{d}$ Department of Geology, Lund University, Sweden

3 e AMS Laboratory, Scottish Universities Environmental Research Centre, East Kilbride G75 OQF, Scotland, $U K$

\section{Abstract}

The Younger Dryas (YD) is a well-constrained cold event from 12,900 to 11,700 years ago

but it remains unclear how the cooling and subsequent abrupt warming recorded in ice cores 9 was translated into ice margin fluctuations in Greenland. Here we present ${ }^{10} \mathrm{Be}$ surface 20 exposure ages from three moraines in front of local glaciers on a $50 \mathrm{~km}$ stretch along the 1 north coast of Greenland, facing the Arctic Ocean. Ten ages range from $11.6 \pm 0.5$ to $27.2 \pm$ $220.9 \mathrm{ka}$ with a mean age of $12.5 \pm 0.7 \mathrm{ka}$ after exclusion of two outliers. We consider this to be 3 a minimum age for the abandonment of the moraines. The ages of the moraines are 4 furthermore constrained using Optically Stimulated Luminescence (OSL) dating of epishelf 5 sediments, which were deposited prior to the ice advance that formed the moraines, yielding 6 a maximum age of $12.4 \pm 0.6 \mathrm{ka}$, and bracketing the formation and subsequent abandonment 27 of the moraines to within the interval 11.8-13.0 ka ago. This is the first time a synchronous 8 YD glacier advance and subsequent retreat has been recorded for several independent 9 glaciers in Greenland. In most other areas, there is no evidence for re-advance and glaciers 0 were retreating during YD. We explain the different behaviour of the glaciers in 1 northernmost Greenland as a function of their remoteness from the Atlantic Meridional 2 Overturning Circulation (AMOC), which in other areas has been held responsible for 33 modifying the YD drop in temperatures. 


\section{Introduction}

The Younger Dryas (YD) marks a cold period at the end of the last glaciation, from 12.9 to 11.7 ka ago (Rasmussen et al., 2006). In spite of rising insolation during the YD, temperatures dropped, probably because the Atlantic Meridional Overturning Circulation (AMOC) was reduced or even shut down by large amounts of meltwater running off the melting ice sheets (Broecker et al., 1989; Denton et al., 2005; Carlson, 2013). The YD is especially pronounced in areas bordering the North Atlantic, and nowhere is it seen more clearly than in ice cores from the top of the Greenland ice sheet where the oscillation began with a c. $6^{\circ} \mathrm{C}$ drop in temperatures over a period of 200 years, and ended with an abrupt rise of c. $10^{\circ} \mathrm{C}$ over a period of only 60 years (Steffensen et al., 2008; Buizert et al., 2014).

Knowledge about how these abrupt climate changes are translated into ice marginal behaviour along the Greenland ice sheet is of importance for evaluating the impact of future warming on the ice margin.

Here we present new evidence of a YD advance and subsequent retreat by three outlet glaciers from the North Cap, the local ice cap over the North Greenland mountain range (Fig. 1). The maximum positions of this advance in respective valley are marked by prominent terminal moraines, which ages are determined by new and previously published surface exposure ages, combined with previously published Optically Stimulated Luminescence (OSL) ages. We furthermore discuss the implications of our findings in the view of previous studies on the YD ice margin behaviour in other parts of Greenland.

2. Study area

The north coast of Greenland represents the land area closest to the North Pole. It comprises a 10 to $15 \mathrm{~km}$ wide coastal plain, bordered to the south by $500-1500 \mathrm{~m}$ high mountains. The coastal plain and connected valleys impinging into the mountain range southwards, host

60 landforms and sediments recording glacial and marine events since the Last Glacial

61 Maximum (LGM) in Greenland (Larsen et al., 2010). Based on the distribution of erratic boulders it was established that a local ice cap, the North Cap, developed over the mountain range in Peary Land during LGM, which to the south and southeast merged with the Greenland ice sheet (Koch, 1923; Dawes, 1986; Funder, 1989). On the coastal plain, erratics, till fabric measurements, and striations show that the outlet glaciers from the local ice caps merged with the Greenland ice sheet to form shelf-based ice in the Arctic Ocean that was deflected eastwards along the coast (Funder and Larsen, 1982; Dawes, 1986; Larsen et al., 
2010; Jakobsson et al., 2014). The deflection of the glaciers was most likely a result of buttressing by thick multiyear (palaeocrystic) sea ice in the Arctic Ocean (Bradley and England, 2008), which forced the local glaciers from Peary Land to flow along the coast (Larsen et al., 2010; Jakobsson et al., 2014). During the initial deglaciation large epishelf lakes were formed between the shelf-based ice and the mountains (Larsen et al., 2010; Möller et al., 2010). In these lakes, thick successions of laminated glaciolacustrine sediments were deposited on the coastal plain and in Sifs valley up to an elevation of $110 \mathrm{~m}$ a.s.l. (Figs. 2-3). OSL ages of the epishelf lake sediments ranged from 135 to $12.4 \mathrm{ka}$ and the large spread suggests that they were differently affected by incomplete bleaching, with the youngest age serving as a maximum age for the deposition of the glaciolacustrine sediments (Larsen et al., 2010; Möller et al., 2010). During the final break-up of the shelf-based ice at 10.1 cal. ka BP the coastal plain and the major valleys were inundated and marine sediments were deposited up to $40 \mathrm{~m}$ a.s.1. (Möller et al., 2010; Funder et al., 2011a). The isostatic uplift of the coastal plain following the deglaciation left a succession of beach ridges with driftwood that was used to constrain the Holocene sea ice history in the Arctic Ocean (Funder et al., 2011a). Following the deglaciation the local glaciers re-advanced through all major valleys along the coast and formed major terminal moraines on the coastal plain. Previously one of these moraines (Constable Bugt) was dated to between 9.6 and $6.3 \mathrm{cal}$. ka BP and there was further evidence of a second re-advance in Sifs Valley between 5.5-5.0 cal. ka BP (Möller et al., 2010). The two Holocene re-advances were linked to increased precipitation caused by more open water conditions in the Artic Ocean during the warm Holocene Thermal Maximum. Our new results indicate that the moraine originated earlier, during the YD.

\section{Methods}

Ten samples from three terminal moraines on the coastal plain at Henson Bugt, Constable Bugt and Bliss Bugt were collected for surface exposure dating in this study (Fig. 2). Eight boulders were sampled using hammer and chisel, as well as a rock drill. The sampled boulder lithologies are meta-sandstone and quartz (Table 1). Two amalgamated pebble samples were collected from the sediment surface; rounded milky quartz pebbles were collected in sample bags in the field and split into uniform size categories (uniform a, b, c axis) before crushing. Sample locations and elevations were recorded in the field with a hand-held GPS. Clinometer measurements were taken for each sample for determination of the site-specific topographic shielding. Sample thickness was noted in the field (checked before crushing), as well as observations with regard to potential weathering loss (e.g. surface roughness, ventifacts, 
102 differential weathering, striae) and snow shielding (e.g. geomorphology, snow patch distribution, lichen distribution and type).

\section{$3.1{ }^{10} \mathrm{Be}$ sample preparation and ${ }^{10} \mathrm{Be}$ age calculation}

106 All rock samples were crushed at the Swedish Museum of Natural History (Stockholm), and 107 processed at the School of Geographical and Earth Sciences (University of Glasgow). The $108 \quad 0.25-0.5 \mathrm{~mm}$ fraction from crushing and pulverizing was enriched with respect to quartz by treatment with $\mathrm{HCl} / \mathrm{HNO}_{3}$, magnetic separation, and $\mathrm{H}_{3} \mathrm{PO}_{4}$. Purification of the quartz

110 fraction was done by successive $\mathrm{HF} / \mathrm{HNO}_{3}$ leaches, and purity (i.e. [Al] $<100 \mu \mathrm{g} / \mathrm{g}$ ) was assessed by measuring the $\mathrm{Al}$ concentration using flame atomic absorption spectrometry

112 (AAS) and inductively coupled plasma optical emission spectrometry (ICP-OES).

113 Preparation of samples for Be measurement was done at the Glasgow University -

114 Scottish Universities Environmental Research Centre (GU - SUERC) Cosmogenic Isotope

115 Laboratory, following procedures modified from Child et al. (2000). After carrier addition

116 (see Table 1 for amounts and concentrations), clean quartz (11-27 g) was dissolved in $40 \%$

$117 \mathrm{HF}$. Be was extracted from solution by anion and cation exchange, precipitated as $\mathrm{Be}(\mathrm{OH})_{2}$,

118 dried and oxidized to $\mathrm{BeO}$. AMS targets were made by mixing $\mathrm{BeO}$ and $\mathrm{Nb}(1: 6)$ and

119 pressing this into cathodes. The ${ }^{10} \mathrm{Be} /{ }^{9} \mathrm{Be}$ of these targets were measured at the SUERC AMS

120 facility (Xu et al., 2010), and normalised to a nominal value of NIST SRM 4325 of $3.06 \times 10^{-}$

$121{ }^{11}$. Samples were prepared and measured between 2007 and 2013. Corresponding process

122 blanks gave ${ }^{10} \mathrm{Be} /{ }^{9} \mathrm{Be}$ ratios between 1.7 and $6.1 \times 10^{-15}$ (see Table 1 for sample/blank ratios

123 and uncertainties). The calculated ${ }^{10} \mathrm{Be}$ concentrations have $1 \sigma$ analytical errors between 3.4

124 and $6.0 \%$.

125 The CRONUS-Earth online calculator was used to estimate surface exposure ages

126 from the calculated ${ }^{10} \mathrm{Be}$ concentrations (Balco et al., 2008). We report exposure ages $( \pm 1 \sigma$,

127 Table 1) calculated according to the St scaling scheme using the Arctic ${ }^{10} \mathrm{Be}$ production rate

128 from Young et al. (2013b) (spallation-induced production rate of $3.93 \pm 0.15$ atoms g $\mathrm{g}^{-1} \mathrm{a}^{-1}$,

129 CRONUS-Earth; Alternate calibration data sets, Wrapper script 2.2, Main calculator 2.1,

130 constants 2.2.1, muons 1.1) (Balco et al., 2008). The Arctic production rate is appropriate

131 because of its geographic coverage and because the calibration data set extends back to ca. 16

132 ka. The analytical uncertainties are used when comparing results internally (i.e. ${ }^{10} \mathrm{Be}$ data

133 only), whereas the systematic uncertainty (parentheses, last column, Table 1) should be used 
when comparing the results with ages obtained using different cosmogenic nuclides or independent dating methods.

No correction for erosion, snow cover or landform degradation has been applied, but this does not mean that these factors are irrelevant - just hard to constrain. Erosion is very lithology specific, ranging from close to zero (amorphous quartz pebbles), granular weathering (meta-sandstones), to random loss of pieces (quartz veins/lenses). Snow cover can potentially be present most of the year, but no data on duration, thickness and density is available. Landform degradation encompasses several processes, such as wind deflation (evident from pebble lags) and freeze-thaw activity (polygonal cracking patterns, ice-wedge polygons and patterned ground), transforming the ridges from their initial unknown geometry to the present-day gently sloping features.

\section{Results}

\subsection{Henson Bugt}

149 In Henson Bugt, a large terminal moraine is located $\sim 10 \mathrm{~km}$ from the present ice margin of a local glacier draining a small ice cap (Fig. 2). The $\sim 30-40 \mathrm{~m}$ high and $\sim 600 \mathrm{~m}$ wide moraine displays occasional large boulders of which three were sampled for surface exposure dating (Fig. 4). The small diameter of lichens on the boulder surfaces suggests an age of only 100 years (E.S. Hansen, pers.com.). However, the 'lichen-kill' effect of semi-permanent snowbeds in the recent past (Lévesque and Svoboda, 1999; Matthews, 2005) would hamper the applicability of lichenometric dating. Three boulder samples (PEA 0719, 0720, 0721) yield ${ }^{10} \mathrm{Be}$ surface exposure ages of $12.5 \pm 0.6,13.5 \pm 0.7$, and $12.4 \pm 0.6 \mathrm{ka}$ (Table 1, Fig. 3), revealing statistically indistinguishable ages, allowing a mean arithmetic age of $12.8 \pm 0.8 \mathrm{ka}$ to be calculated.

\subsection{Constable Bugt}

161 In Constable Bugt, a 60 to $100 \mathrm{~m}$ high and $\sim 1 \mathrm{~km}$ wide terminal moraine blocks the entrance to Sifs Valley (Figs. 2, 5). The moraine, located $\sim 17 \mathrm{~km}$ from the present valley glacier margin, has a core composed of diamict and, in addition to this, glaciotectonically up-

164 thrusted fine-grained glaciolacustrine sediments on its proximal part (Möller et al., 2010). Six 165 processed samples (PEA 0611, 0613, 0618, 0621, 0645, 0647) range from $11.6 \pm 0.5$ to 27.2 $166 \pm 0.9 \mathrm{ka}$ (Table 1, Fig. 3). From its stable setting, cobble on bedrock, sample PEA 0647 is 167 expected to provide the most reliable ${ }^{10} \mathrm{Be}$ surface exposure age (assuming no inheritance), 
and this cobble gives $12.6 \pm 0.7 \mathrm{ka}$. Samples PEA 0613, 0618, 0645 and 0647 yield statistically indistinguishable ages, resulting in an arithmetic mean age of $12.1 \pm 0.6 \mathrm{ka}$ for the moraine ridge. The two older ${ }^{10} \mathrm{Be}$ surface exposure ages can likely be explained by inheritance. Occasional boulders showing inheritance are to be expected, however, the amalgamated pebble sample (PEA 0611) yields the oldest age, suggesting that the re-worked material comprising the moraine has a complex exposure history prior to moraine ridge formation.

\subsection{Bliss Bugt}

In Bliss Bugt a $\sim 10-30 \mathrm{~m}$ high moraine is located $\sim 8 \mathrm{~km}$ from the present ice margin of Moore Glacier (Fig. 2). The surface consists of sorted coarse-grained sediments with few scattered boulders (Fig. 6). One amalgamated sample of surface pebbles from the sediment ridge gives a ${ }^{10} \mathrm{Be}$ surface exposure age of $12.8 \pm 0.7 \mathrm{ka}$ (Table 1, Fig. 3). This sample was included in the study by Möller et al. (2010), but because its ${ }^{10} \mathrm{Be}$ surface exposure age was considered to be an outlier (significantly older than the data set from Bliss Bugt at that time), no conclusions were drawn. However, since the age overlaps with the new ${ }^{10} \mathrm{Be}$ data from the moraine ridges at Constable Bugt and Henson Bugt we find it to be reliable.

\section{Discussion}

\subsection{Younger Dryas moraines in North Greenland}

In total, we dated eight boulders and two amalgamated pebble samples from the moraines on the north coast of Greenland. Two samples are significantly older than the rest and considered as outliers, suffering from inheritance. However, the consistent ages of the majority of samples suggest that inheritance is not a significant problem; otherwise a more scattered age distribution would have been expected, such as noted for erratics on moraines in Scoresby Sund (Kelly et al., 2008). We attempted to minimize the post-depositional effects by sampling the largest boulders on the flat surface of the moraine crests at Henson Bugt and Constable Bugt. Long-term moraine degradation also plays an insignificant role in West Greenland where the Fjord Stade moraines were precisely dated to 9.3 and 8.2 ka by ${ }^{10} \mathrm{Be}$ measurements, controlled by threshold lake records (Young et al., 2011; Young et al., 2013a). These uncertainties, in addition to other processes such as shielding by long lasting snow cover, moraine degradation where boulders are slowly exhumed until the moraine stabilizes, or because of dead-ice melting (Heyman et al., 2011; Houmark-Nielsen et al., 2012), have the potentials of making the ages too young. We therefore treat all ages as minimum ages. 
Accordingly, we calculate an arithmetic mean minimum age of $12.5 \pm 0.7 \mathrm{ka}(\mathrm{n}=8)$, excluding the two outliers mentioned above (Fig. 7).

Clearly, our new ${ }^{10} \mathrm{Be}$ results yielding a YD age of the moraines seems incompatible with our previous interpretation which suggests an age between 9.6 and $6.3 \mathrm{cal}$. ka BP (Möller et al., 2010). However, the two interpretations are not necessarily mutually exclusive. The consistency of ${ }^{10} \mathrm{Be}$ ages on three independent moraines along $50 \mathrm{~km}$ of coast is very compelling. So is also the radiocarbon age $(\sim 10.3 \mathrm{cal} . \mathrm{ka} \mathrm{BP})$ of the glaciotectonically upthrusted sediments on the proximal side of the moraine in Constable Bugt (site CB0705; Fig. 5 in Möller et al., 2010), suggesting a younger age for this part of the moraine. With the new ${ }^{10} \mathrm{Be}$ ages along the major part of the Constable Bugt moraine, we suggest that its core was

212 formed during the YD advance, while the up-thrusted sediments on its proximal side are

213 related to a younger re-advance between 9.6 and 6.3 cal. ka BP (Fig. 8). Given that the 214 coastal plain was inundated $10.1 \mathrm{cal}$. ka BP, following the break-up of the ice on the shelf,

215 marine sediments were deposited on the distal part of the moraine up to $40 \mathrm{~m}$ a.s.l. in

216 Constable Bugt. Thus, the surficial diamict with molluscs ( 10.1 and 9.6 cal. ka BP) located

217 below the marine limit (site CB0706; Fig. 5 in Möller et al., 2010) is re-interpreted. We thus

218 suggest it represents a marine drop till or, more likely, a young solifluction lobe with

219 diamictized marine sediment on the distal part of the moraine, rather than being glacially remoulded marine sediment from the interior of Sifs valley at terminal moraine formation, as suggested by Möller et al. (2010).

We can furthermore constrain the age of moraines by re-evaluating the retrieved OSL ages of the epishelf sediments, deposited during the break-up of the LGM shelf-based ice and before the moraines were formed (Larsen et al., 2010; Möller et al., 2010). The large spread of older OSL ages, from 135 to as young as $12.4 \mathrm{ka}$, with the youngest ages likely a maximum age interval for the formation of the moraines as discussed above (Figs. 3, 7). Besides giving a lower age constrain for the moraine, the presence of epishelf sediments in Sifs valley furthermore demonstrates that the glacier advanced to the moraine from up-valley, i.e. the moraine was not formed by still-stand during stepwise deglaciation.

In summary, the age of the moraines are bracketed by the minimum limiting ${ }^{10} \mathrm{Be}$ surface exposure ages of $12.5 \pm 0.7$ and the maximum limiting OSL age of $12.4 \pm 0.6 \mathrm{ka}$, implying that the moraines were formed and abandoned within an age interval of 11.8-13.0 ka. The ${ }^{10} \mathrm{Be}$ surface exposure ages are derived from three terminal moraines formed by

234 independent glaciers over a distance of $50 \mathrm{~km}$. This indicates that the glaciers advanced as a response to external climate forcing rather than local topography or surging, and we conclude 
that the moraines formed during an advance in response to the YD cooling. However, the large uncertainties both in surface exposure and OSL ages preclude an assessment of the duration of moraine formation, and its more precise age within the YD.

241 In other parts of Greenland the ice margin response to the YD cooling is more ambiguous.

242 This is seen from recent ${ }^{10} \mathrm{Be}$ surface exposure dating of moraines and detailed seismic 243 studies on the shelf, accompanied by AMS ${ }^{14} \mathrm{C}$-dated marine cores (Fig. 9). Below is a brief review of the evidence and the climatic background given by the authors.

\subsubsection{East Greenland}

In the East Greenland Fjord Zone, between $70^{\circ}$ and $77^{\circ} \mathrm{N}$, a belt of moraines - the Milne Land moraines - were formed by outlet glaciers from the ice sheet at the mouths of all major fjords (Fig. 9). The moraines occur in swarms forming a generally 5-10 km but up to $25 \mathrm{~km}$ wide belt. Distinct weathering limits between the outer moraines and the terrain distal to them and also their impressive dimensions - probably the highest and longest moraine ridges in Greenland - suggest that the moraine formation began with a re-advance after a period when the glaciers had been farther back in the fjords (Hjort, 1981; Funder, 1989; Landvik, 1994). In support of this, marine cores from the outer fjord area of Scoresby Sund may indicate that, this part of the fjord was deglaciated already during the Allerød (Marienfeld, 1992; Dowdeswell et al., 1994; Funder et al., 1998). Cessation of ice rafted debris (IRD) deposition on the shelf along the fjord zone during the Bølling (c. $13.8 \mathrm{ka} \mathrm{cal}$. BP), suggests that, by this time, the major outlet glaciers had retreated from the inner shelf and terminated in the fjords where a large part of their IRD was trapped (Stein et al., 1993;

260 Funder et al., 1998). Concordantly, this evidence suggests that the outer Milne Land moraines were formed during re-advance or a long lasting still stand, and not as a step during deglaciation.

Results from radiocarbon dating of marine shells associated with the Milne Land moraines indicate that, in the entire region, the belt of moraines was abandoned and rapid deglaciation begun by the end of the Preboreal Oscillation (11.3-11.15 ka cal. BP) (Björck et al., 1997). Both in Scoresby Sund and on Hochstetter Forland, $500 \mathrm{~km}$ to the north, the moraine formation was accompanied by a fall of 30-40 $\mathrm{m}$ in relative sea level from the outer to the inner moraine, suggesting that they were formed during a protracted period of time (Funder, 1978; Hjort and Björck, 1984; Hall et al., 2010). This has later been confirmed by an 
extensive dataset comprising both ${ }^{10} \mathrm{Be}$ exposure and AMS ${ }^{14} \mathrm{C}$ ages from the moraines in

271 Scoresby Sund. These data indicate that the advance of the region's largest outlet glacier most likely culminated in late Allerød times (>12.9 ka cal. BP), and that moraine formation ceased at 11-11.2 ka cal. BP (Hall et al., 2008). ${ }^{10}$ Be surface exposure dating of erratic boulders on moraines from a local ice cap, correlated with the Milne Land moraines, gives a slightly older age for the period, from 13 to $11.6 \mathrm{ka}$ (Kelly et al., 2008).

Unfortunately the time resolution of the dating prevents conclusions about the character of the retreat from the oldest moraines - whether it was gradual or punctuated by significant re-advance, or possibly even consisted of only two distinct re-advances - one in late Allerød times and the other in the late Preboreal, because no moraines have been directly dated to YD, neither in Scoresby Sund, nor in more northerly areas. Hjort and Björck (1984) suggested that the moraines on Hochstetter Forland were separated by an ice free interval, followed by a re-advance, and Denton et al. (2005) and Hall et al. (2010) suggested that the Preboreal re-advance could have obliterated the missing moraines from late YD. Still, even though no moraines have been dated to the YD, it is a reasonable assumption that the glacier fronts were located within the zone of the Milne Land moraines during the YD, and could be represented by undated moraines between the outer and inner Milne Land moraines. This would imply that the YD here was a period of oscillatory retreat within a narrow a zone.

Denton et al. (2005) noticed a mismatch between the YD temperatures deduced from moraine altitudes and those derived from borehole temperatures in nearby ice cores. It was suggested that while the borehole temperatures record mean annual temperature, the equilibrium-line altitudes deduced from moraines, mainly reflect summer temperatures. This implies that the YD temperature drop was mainly a winter phenomenon with little effect on the ice margin. This increase in seasonality was seen as a result of a reduction in the AMOC, which led to increased sea ice and reduced inflow of advective heat to the North Atlantic (Denton et al., 2005).

In contrast to this, in the Kangerlussuaq area to the south $\left(\right.$ c. $\left.67^{\circ} \mathrm{N}\right)$, both shelf and fjord experienced large-scale retreat of the ice sheet margin in the YD (Fig. 9). This was shown by the occurrence of light isotopes in foraminifer shells from marine sediments on the shelf, as well as onset of IRD deposition during YD, which indicate a large supply of meltwater and break-up of the ice sheet margin (Jennings et al., 2006). A "major construction feature" c. $50 \mathrm{~km}$ off the coast could be a YD terminal moraine (Andrews et al., 1997), and is the only possible indication of re-advance during or before YD. It was suggested that the massive retreat was caused by advection of warm Atlantic intermediate water through the 
Irminger Current, which overruled the climatic cooling. This should also have persisted when the ice margin retreated into the long and deep fjord, which was almost completely deglaciated during late YD, as shown recently by ${ }^{10}$ Be surface exposure ages (Dyke et al., 2014).

\subsubsection{Southeast Greenland}

Farther to the south, at Sermilik $\left(66^{\circ} \mathrm{N}\right)$ and Bernstorffs Fjord $\left(64^{\circ} \mathrm{N}\right)\left(\right.$ Fig. 9), ${ }^{10} \mathrm{Be}$ surface exposure ages and ${ }^{14} \mathrm{C}$ ages lake sediments show that large outlet glaciers here remained on the inner shelf until c. 11 ka (Long et al., 2008; Roberts et al., 2008; Dyke et al., 2014; Larsen et al., 2015). Apparently the warm Irminger Current water did not reach this coast and ice margin, in spite of its appearance at the shelf break outside Bernstorffs Fjord, as shown by sea-bed and core data (Kuijpers et al., 2003). Here, the warm Irminger Current water appeared already at $14.5 \mathrm{cal}$. ka BP, continuing through the YD with no apparent increase in sea ice or reduction in AMOC (Kuijpers et al., 2003; Knutz et al., 2011). It is difficult to reconcile the land and marine records from this area, especially since the shelf here has a width of only $50 \mathrm{~km}$, but the ice sheet margin apparently stayed on the inner shelf during the YD.

\subsubsection{South Greenland}

In a marine sediment core from the Eirik Drift to the south of Greenland's southern tip (c. $58^{\circ} \mathrm{N}$ ) Carlson et al. (2008) found an increase in Greenland detritus during YD, implying increased runoff from the ice sheet (Fig. 9). This is in agreement with evidence from isolation lakes in the Nanortalik district in southernmost Greenland, indicating rapid uplift, i.e. ice thinning retreat, especially during the late YD (Sparrenbom et al., 2006). In a lake core near the southern tip of Greenland $\left(\mathrm{c} .60^{\circ} \mathrm{N}\right)$ - the only lake sediment record in Greenland reaching beyond YD - the Allerød/YD transition is characterized by an increase in lake productivity and occurrence of a warmth demanding diatom, indicating that YD was warmer than Allerød (Björck et al., 2002). This “anomalous" warming was explained as a result of reduced AMOC and increased sea ice and seasonality (Björck et al., 2002). This is the same mechanism that was proposed to afford the glacier advance in Scoresby Sund, but here in the south the increased seasonality resulted in summer temperatures that were high enough to promote melting. It is notable that the beginning of the Holocene in this lake is marked by a sharp transition from minerogenic to organic sediment - akin to the boundary 
seen in NW European lakes, and so far the only evidence of the abrupt warming at the end of the YD found in ice-free Greenland.

\subsubsection{West Greenland}

In West Greenland, outlet glaciers in all major fjords coalesced on the shelf. Here, two large moraine systems, the Hellefiske and Fiskebanke moraines were traced for c. 500 km during oil-prospecting in the 1970's (Kelly, 1985; Funder et al., 2011b) (Fig. 9). The Hellefiske moraine follows the shelf edge, while the Fiskebanke moraine reflects a lobate ice sheet margin on the inner shelf and in the shelf troughs. These moraines have alternatively been referred to as Saalian/LGM or LGM/YD in their formation (Funder et al. 2011). Recent results from Disko Bugt show that a large outlet glacier reached the shelf edge, more than $200 \mathrm{~km}$ off the coast, at the LGM (see below), suggesting that the ice sheet margin also reached the much narrower shelf edge farther south, and that the oldest of the moraines were not older than the LGM. However, as none of the moraines have yet been dated, and as no YD moraines have so far been observed elsewhere in West Greenland, it remains an open question if either the Hellefiske or Fiskebanke moraines were formed during the YD, but recent ${ }^{10} \mathrm{Be}$ surface exposure ages from coastal areas show that the ice sheet margin remained on the shelf in this part of Greenland up until shortly before 11 or even $10 \mathrm{ka}$ ago (Roberts et al., 2009; Larsen et al., 2014).

In Disko Bugt, the largest drainage trough in western Greenland $\left(\mathrm{c} .70^{\circ} \mathrm{N}\right),{ }^{14} \mathrm{C}$ ages of shells from marine cores show that the large ice stream, which occupied the trough outside Disko Bugt, may have begun its retreat at 13.8 cal. ka BP (Fig. 9) (O'Cofaigh et al. 2012). However, by c. 12.2 cal. ka BP, in mid-YD times, the retreat was interrupted by a short-lived re-advance almost to the shelf edge, followed by "instantaneous" collapse (O'Cofaigh et al., 2012; Kelley et al., 2013; Jennings et al., 2014; Rinterknecht et al., 2014). The re-advance amounted to almost $100 \mathrm{~km}$ along a c. $50 \mathrm{~km}$ wide front. This is seen from ${ }^{14} \mathrm{C}$ ages of shells from marine cores, both incorporated in till and in situ in the overlying marine mud on the inner shelf (O'Cofaigh et al., 2012; Rinterknecht et al., 2014). The collapse brought the ice margin back from the shelf-edge c. $200 \mathrm{~km}$ to the mouth of Disko Bugt (Fig. 9). The short duration of this re-advance/retreat suggests that it could represent a surge of a thin glacier lodged in the trough and controlled by subglacial topography and ice thickness, and not directly by the YD cooling (O'Cofaigh et al., 2012). Both before and especially after the readvance, the Disko Bugt glacier retreated rapidly over the shelf through large-scale calving (Jennings et al., 2014). ${ }^{10}$ Be surface exposure ages from the coastal area at the mouth of 
371 Disko Bugt show that deglaciation of the bay began between 12.2 and 11.6 ka ago (Kelley et al., 2013; Rinterknecht et al., 2014). According to Rinterknecht et al. (2014) the collapse of the shelf-bound part of the Disko Bugt ice stream was triggered by the arrival of warm subsurface water as a result of a reduced AMOC.

\subsubsection{Northwest Greenland}

Farther north, in the Uummannaq Trough $\left(\right.$ c. $\left.71^{\circ} \mathrm{N}\right),{ }^{14} \mathrm{C}$ dated marine cores show that deglaciation from the outer shelf began c. 14.8 cal. ka BP, and ${ }^{10} \mathrm{Be}$ surface exposure ages from coastal mountains show that by $12.4 \mathrm{ka}$ ago the outer and mid shelf, as well as the mountains, were cleared of ice (Fig. 9). After this, the recession picked up speed, and in the following millennium $100 \mathrm{~km}$ of the fjords were deglaciated (Roberts et al., 2013). Accordingly, the YD, and especially its mid and late parts, appears to be a period of retreat. Along the northwest coast of Greenland, the YD ice sheet margin was also located on the shelf. A marine core from the entrance to Nares Strait between Canada and Greenland (c. $77^{\circ} \mathrm{N}$ ) shows that the cored site was deglaciated before $12.5 \mathrm{cal}$. ka BP and that meltwater

\subsection{Synthesis of the Greenland ice sheet's response to the YD cooling}

As noted above, the circumstance that three major glaciers over a distance of $50 \mathrm{~km}$ from east to west advanced and retreated synchronously imply that this advance was not caused by local forcing, such as the short-lived re-advance on the shelf off Disko Bugt, but by external, climatic factors. Surprisingly, the survey of ice margin behavior in other parts of Greenland shows that no other moraines have been dated to the YD, although some moraines are under discussion (Fig. 9). The Milne Land moraines, the only other evidence in Greenland for significant late glacial ice margin re-advance, apparently culminated in late Allerød times, but smaller re-advances of the outlet glaciers may have occurred during YD, represented by undated moraines in the area. In more southerly areas, wherever a record is available, the ice margins seem to have retreated from the shelf and in the fjords as shown by the records from Kangerlussuaq, Nanortalik, Uumannaq Fjord and especially Disko Bugt, where the retreat in late YD amounted to large scale collapse (Jennings et al., 2006; Sparrenbom et al., 2006; Carlson et al., 2008; O'Cofaigh et al., 2012; Roberts et al., 2013; Dyke et al., 2014; Jennings et al., 2014; Rinterknecht et al., 2014).

There is therefore a striking mismatch between the dramatic cooling and later abrupt warming seen in ice cores, and the retreat of the ice margins at most sites where a record is 
available. This has generally been explained as a result of a reduction in AMOC and accompanying increase of seasonality (Björck et al., 2002, Denton et al., 2005, Carlson et al., 2008, Hall et al., 2008, Kelly et al., 2008, Rinterknecht et al., 2014). The reduced AMOC is thought to have been caused by a large supply of meltwater to the North Atlantic from melting ice sheets, which freshened the sea surface and reduced the advection of heat into the North Atlantic. This in turn increased sea ice extent, which sealed the ocean from exchange with the atmosphere, resulting in higher seasonality in Greenland. In addition, reduction in the AMOC may also have increased production of warm subsurface water at low latitudes, which advected northwards and promoted melting of shelf-bound ice margins (Marcott et al., 2011), as noted for the shelf-bound ice margins at Kangerlussuaq and Disko Bugt (Jennings et al., 2006, Rinterknecht et al., 2014).

These mechanisms may explain why the cold oscillation seen in ice cores did not lead to significant re-advance, and all processes are tied up to oceanographic perturbations originating in the North Atlantic. It is therefore noteworthy that areas with significant YD ice margin retreat in Greenland all are located in areas which today lie alongside the warm Irminger and Greenland Currents, which transport warm Atlantic water to the coasts of Southeast and West Greenland, while the areas with advance or sluggish retreat - Peary Land and the East Greenland Fjord Zone - are outside this realm (Fig. 9). This underlines Carlson et al.'s (2008) contention that ice sheets responded differently to cooling, depending on their geographic distribution relative to heat transport. In concert with this, Buizert et al. (2014) from analyses of ice cores showed that YD seasonality, a measure of the AMOC intensity, decreases from south to north, away from the influence of warm Atlantic water. We suggest that the reason for the YD glacier advance/retreat in Peary Land, at a time when ice margins generally retreated, may lie in the respective distances of these areas from North Atlantic advective heat, with Greenland's north coast being the farthest away. However, the coupling between the YD cooling and the subsequent glacier response remains enigmatic, in part because there are very few well-dated sites from this period in Greenland.

\section{Conclusion}

434 We have constrained the age of three terminal moraines in front of local glaciers along a 50

$435 \mathrm{~km}$ stretch on the north coast of Greenland, using OSL and surface exposure dating

436 techniques. The minimum limiting ${ }^{10} \mathrm{Be}$ surface exposure ages on erratics on the moraines

437 show a mean age of $12.5 \pm 0.7 \mathrm{ka}$ and the maximum limiting OSL age for epishelf-lake

438 sediments immediately preceding moraine formation give an age of $12.4 \pm 0.6 \mathrm{ka}$. These ages 
bracket the formation and subsequent abandonment of the moraines to within the interval

$440 \quad 11.8-13.0 \mathrm{ka}$. The synchronous advance of independent glaciers suggests that they responded

441 to external climate forcing rather than being controlled by topography or being the result of

442 glacier surging. Occurrence of older glaciolacustrine sediments up valley from one of the

443 moraines shows that this valley was ice free before the advance, and this is the first record of

444 YD glacier re-advance/retreat in Greenland. In all other studied areas of Greenland the ice

445 margins were retreating at this time, probably sluggishly in northern East Greenland, but

446 rapidly in more southerly areas. The difference in ice margin response to the YD cooling may

447 be explained by distance to the AMOC, with East and North Greenland being the farthest

448 away. Where data are available, the retreat began before YD, and there is so far none, or

449 little, evidence of a direct ice margin response, neither to the early YD cooling nor to the

450 subsequent rapid Preboreal warming. This may to some extent owe to the limits of the

451 available dating techniques and inaccessibility of critical sites, but in the light of the ongoing

452 warming and its dramatic effect on the Greenland ice sheet, the problem deserves more

453 attention.

454

455

Acknowledgements

456 The Danish National Research Council (FNU), Carlsbergfondet and the Swedish Research

457 Council (VR) supported the project. NKL acknowledges support from Villum Fonden.

458 Laboratory analyses benefited from internal funding from the Bjerknes Centre for Climate

459 Research, HL thanks the Swedish Museum of Natural History for access to their crushing 460 facilities, and Maria Miguens-Rodriguez, Delia Gheorghiu, Hannah Mathers, Fotini 461 Karakitsos and Alessa Geiger for assistance during laboratory processing of the samples. Eric 462 Steen Hansen and Eske Willerslev provided field assistance. We thank Guest editor Jason 463 Briner, Nicolas Young and an anonymous reviewer for their constructive comments, which 464 helped improve the manuscript.

465

466 References

467 Andrews, J.T., Smith, L.M., Preston, R., Cooper, T., Jennings, A.E., 1997. Spatial and 468 temporal patterns of iceberg rafting (IRD) along the East Greenland margin, ca 68 469 degrees N, over the last 14 cal ka. Journal of Quaternary Science 12, 1-13.

470 Balco, G., Stone, J.O., Lifton, N.A., Dunai, T.J., 2008. A complete and easily accessible 471 means of calculating surface exposure ages or erosion rates from Be-10 and Al-26 472 measurements. Quat Geochronol 3, 174-195. 
Björck, S., Bennike, O., Rosen, P., Andresen, C.S., Bohncke, S., Kaas, E., Conley, D., 2002. Anomalously mild Younger Dryas summer conditions in southern Greenland. Geology 30, 427-430.

Björck, S., Rundgren, M., Ingolfsson, O., Funder, S., 1997. The Preboreal oscillation around the Nordic Seas: terrestrial and lacustrine responses. Journal of Quaternary Science 12, 455-465.

Bradley, R.S., England, J.H., 2008. The Younger Dryas and the Sea of ancient ice. Quaternary Res 70, 1-10.

Broecker, W.S., Kennett, J.P., Flower, B.P., Teller, J.T., Trumbore, S., Bonani, G., Wolfli, W., 1989. Routing of Meltwater from the Laurentide Ice-Sheet during the Younger Dryas Cold Episode. Nature 341, 318-321.

Buizert, C., Gkinis, V., Severinghaus, J.P., He, F., Lecavalier, B.S., Kindler, P., Leuenberger, M., Carlson, A.E., Vinther, B., Masson-Delmotte, V., White, J.W.C., Liu, Z.Y., OttoBliesner, B., Brook, E.J., 2014. Greenland temperature response to climate forcing during the last deglaciation. Science $345,1177-1180$.

Carlson, A., Stoner, J.S., Donnelly, J.P., Hillaire-Marcel, C., 2008. Response of the southern Greenland Ice Sheet during the last two deglaciations. Geology 36, 359-362.

Carlson, A.E., 2013. The Younger Dryas Climate Event. Encyclopedia of Quaternary Science $3,126-134$.

Child, D., Elliott, G., Mifsud, C., Smith, A.M., Fink, D., 2000. Sample processing for earth science studies at ANTARES. Nuclear Instruments and Methods in Physics Research Section B172, 856-860.

Dawes, P.R., 1986. Glacial erratics on the Artic Ocean margin of North Greenland: implications for an extensive ice-shelf. Bulletin of the Geological Society of Denmark $35,59-69$.

Denton, G.H., Alley, R.B., Comer, G.C., Broecker, W.S., 2005. The role of seasonality in abrupt climate change. Quaternary Science Reviews 24, 1159-1182.

Dowdeswell, J.A., Uenzelmannneben, G., Whittington, R.J., Marienfeld, P., 1994. The Late Quaternary Sedimentary Record in Scoresby Sund, East Greenland. Boreas 23, 294310.

Dunne, J., Elmore, D., Muzikar, P., 1999. Scaling factors for the rates of production of cosmogenic nuclides for geometric shielding and attenuation at depth on sloped surfaces. Geomorphology 27, 3-11. 
Dyke, L.M., Hughes, A.L.C., Murray, T., Hiemstra, J.F., Andresen, C.S., Rodes, A., 2014. Evidence for the asynchronous retreat of large outlet glaciers in southeast Greenland at the end of the last glaciation. Quaternary Science Reviews 99, 244-259.

Funder, S., 1978. Holocene stratigraphy and vegetation history in the Scoresby Sund area, East Greenland. Bulletin Grønlands Geologiske Undersøgelse 129, 1-66.

Funder, S., 1989. Quaternary geology of the ice-free areas and adjacent shelves og Greenland, In: Fulton, R.J. (Ed.), Quaternary geology of Canada and Greenland. Geological Survey of Canada, Geology of Canada, pp. 743-792.

Funder, S., Goosse, H., Jepsen, H., Kaas, E., Kjær, K.H., Korsgaard, N.J., Larsen, N.K., Linderson, H., Lysa, A., Möller, P., Olsen, J., Willerslev, E., 2011a. A 10,000-Year Record of Arctic Ocean Sea-Ice Variability-View from the Beach. Science 333, 747750.

Funder, S., Hjort, C., Landvik, J.Y., Nam, S.I., Reeh, N., Stein, R., 1998. History of a stable ice margin East Greenland during the Middle and Upper Pleistocene. Quaternary Science Reviews 17, 77-123.

Funder, S., Kjeldsen, K.K., Kjær, K.H., Ó Cofaigh, C., 2011b. The Greenland ice sheet during the last 300.000 years: a review. Developments in Quaternary Science 15, 699713.

Funder, S., Larsen, O., 1982. Implications of volcanic erratics in Quaternary deposits of North Greenland. Bulletin of the Geological Society of Denmark 31, 57-61.

Gosse, J.C., Phillips, F.M., 2001. Terrestrial in situ cosmogenic nuclides: theory and application. Quaternary Science Reviews 20, 1475-1560.

Hall, B.L., Baroni, C., Denton, G.H., 2008. The most extensive Holocene advance in the Stauning Alper, East Greenland, occured in the Little Ice Age Polar Res 27, 128-134.

Hall, B.L., Baroni, C., Denton, G.H., 2010. Relative sea-level changes, Schuchert Dal, East Greenland, with implications for ice extent in late-glacial and Holocene times. Quaternary Science Reviews 29, 3370-3378.

Heyman, J., Stroeven, A.P., Harbor, J.M., Caffee, M.W., 2011. Too young or too old: Evaluating cosmogenic exposure dating based on an analysis of compiled boulder exposure ages. Earth and Planetary Science Letters 302, 71-80.

Hjort, C., 1981. A Glacial Chronology for Northern East Greenland. Boreas 10, 259-274.

Hjort, C., Björck, S., 1984. A re-evaluation of the glacial chronology in northern East Greenland. Geologiska Foreningens i Stockholm Förhandlingar 105, 235-243. 
Houmark-Nielsen, M., Linge, H., Fabel, D., Schnabel, C., Xu, S., Wilcken, K.M., Binnie, S., 2012. Cosmogenic surface exposure dating the last deglaciation in Denmark: Discrepancies with independent age constraints suggest delayed periglacial landform stabilisation. Quat Geochronol 13, 1-17.

Jakobsson, M., Andreassen, K., Bjarnadottir, L.R., Dove, D., Dowdeswell, J.A., England, J.H., Funder, S., Hogan, K., Ingoolfsson, O., Jennings, A., Larsen, N.K., Kirchner, N., Landvik, J.Y., Mayer, L., Mikkelsen, N., Moller, P., Niessen, F., Nilsson, J., O'Regan, M., Polyak, L., Norgaard-Pedersen, N., Stein, R., 2014. Arctic Ocean glacial history. Quaternary Science Reviews 92, 40-67.

Jennings, A.E., Hald, M., Smith, M., Andrews, J.T., 2006. Freshwater forcing from the Greenland Ice Sheet during the Younger Dryas: evidence from southeastern Greenland shelf cores. Quaternary Science Reviews 25, 282-298.

Jennings, A.E., Walton, M.E., Cofaigh, C.O., Kilfeather, A., Andrews, J.T., Ortiz, J.D., De Vernal, A., Dowdeswell, J.A., 2014. Paleoenvironments during Younger Dryas-Early Holocene retreat of the Greenland Ice Sheet from outer Disko Trough, central west Greenland. Journal of Quaternary Science 29, 27-40.

Kelley, S.E., Briner, J.P., Young, N.E., 2013. Rapid ice retreat in Disko Bugt supported by Be-10 dating of the last recession of the western Greenland Ice Sheet. Quaternary Science Reviews 82, 13-22.

Kelly, M., 1985. A review of the Quaternary geology of western Greenland, In: Andrews, J.T. (Ed.), Quaternary Environments in Eastern Canadian Arctic, Baffin Bay and Western Greenland. Allen and Unwin, Boston, pp. 461-501.

Kelly, M.A., Lowell, T.V., Hall, B.L., Schaefer, J.M., Finkel, R.C., Goehring, B.M., Alley, R.B., Denton, G.H., 2008. A Be-10 chronology of lateglacial and Holocene mountain glaciation in the Scoresby Sund region, east Greenland: implications for seasonality during lateglacial time. Quaternary Science Reviews 27, 2273-2282.

Knudsen, K.L., Stabell, B., Seidenkrantz, M.S., Eiriksson, J., Blake, W., 2008. Deglacial and Holocene conditions in northernmost Baffin Bay: sediments, foraminifera, diatoms and stable isotopes. Boreas 37, 346-376.

Knutz, P.C., Sicre, M.A., Ebbesen, H., Christiansen, S., Kuijpers, A., 2011. Multiple-stage deglacial retreat of the southern Greenland Ice Sheet linked with Irminger Current warm water transport. Paleoceanography 26, Doi 10.1029/2010pa002053.

Koch, L., 1923. Preliminary report upon the geology of Peary Land, Arctic Greenland Am J Sci 5, 190-199. 
573

574

575

576

577

578

579

580

581

582

583

584

585

586

587

588

589

590

591

592

593

594

595

596

597

598

599

600

601

602

603

604

605

606

Kuijpers, A., Troelstra, S.R., Prins, M.A., Linthout, K., Akhmetzhanov, A., Bouryak, S., Bachmann, M.F., Lassen, S., Rasmussen, S., Jensen, J.B., 2003. Late Quaternary sedimentary processes and ocean circulation changes at the Southeast Greenland margin. Marine Geology 195, 109-129.

Landvik, J.Y., 1994. The Last Glaciation of Germania-Land and Adjacent Areas, Northeast Greenland. Journal of Quaternary Science 9, 81-92.

Larsen, N.K., Funder, S., Kjær, K.H., Kjeldsen, K.K., Knudsen, M.F., Linge, H., 2014. Rapid early Holocene ice retreat in West Greenland. Quaternary Science Reviews 92, 310323.

Larsen, N.K., Kjær, K.H., Funder, S., Möller, P., van der Meer, J.J.M., Schomacker, A., Linge, H., Darby, D.A., 2010. Late Quaternary glaciation history of northernmost Greenland - Evidence of shelf-based ice. Quaternary Science Reviews 29, 3399-3414.

Larsen, N.K., Kjær, K.H., Lecavalier, B., Bjørk, A.A., Colding, S., Huybrechts, P., Jakobsen, K.E., Kjeldsen, K.K., Knudsen, K.L., Odgaard, B., Olsen, J., 2015. The response of the southern Greenland ice sheet to the Holocene thermal maximum. Geology 43, 291-294.

Lévesque, E., Svoboda, J., 1999. Vegetation re-establishment in polar "lichen-kill" landscapes: a case study of the Little Ice Age impact. Polar Res 18, 221-228.

Lohne, O.S., Mangerud, J., Birks, H.H., 2013. Precise C-14 ages of the Vedde and Saksunarvatn ashes and the Younger Dryas boundaries from western Norway and their comparison with the Greenland Ice Core (GICC05) chronology. Journal of Quaternary Science 28, 490-500.

Long, A.J., Roberts, D.H., Simpson, M.J.R., Dawson, S., Milne, G.A., Huybrechts, P., 2008. Late Weichselian relative sea-level changes and ice sheet history in southeast Greenland. Earth and Planetary Science Letters 272, 8-18.

Marcott, S.A., Clark, P.U., Padman, L., Klinkhammer, G.P., Springer, S.R., Liu, Z.Y., OttoBliesner, B.L., Carlson, A.E., Ungerer, A., Padman, J., He, F., Cheng, J., Schmittner, A., 2011. Ice-shelf collapse from subsurface warming as a trigger for Heinrich events. Proceedings of the National Academy of Sciences of the United States of America 108, 13415-13419.

Marienfeld, P., 1992. Recent Sedimentary Processes in Scoresby Sund, East Greenland. Boreas 21, 169-186.

Matthews, J.A., 2005. 'Little Ice Age' glacier variations in Jotunheimen, southern Norway: a study in regionally controlled lichenometric dating of recessional moraines with implications for climate and lichen growth rates. Holocene 15, 1-19. 
Möller, P., Larsen, N.K., Kjær, K.H., Funder, S., Schomacker, A., Linge, H., Fabel, D., 2010. Early to middle Holocene valley glaciations on northernmost Greenland. Quaternary Science Reviews 29, 3379-3398.

Muscheler, R., Adolphi, F., Knudsen, M.F., 2014. Assessing the differences between the IntCal and Greenland ice-core time scales for the last 14,000 years via the common cosmogenic radionuclide variations. Quaternary Science Reviews 106, 81-87.

O'Cofaigh, C., Dowdeswell, J.A., Jennings, A.E., Hogan, K.A., Kilfeather, A., Hiemstra, J.F., Noormets, R., Evans, J., McCarthy, D.J., Andrews, J.T., Lloyd, J.M., Moros, M., 2012. An extensive and dynamic ice sheet on the West Greenland shelf during the last glacial cycle. Geology 41, 219-222.

Rasmussen, S.O., Andersen, K.K., Svensson, A.M., Steffensen, J.P., Vinther, B.M., Clausen, H.B., Siggaard-Andersen, M.L., Johnsen, S.J., Larsen, L.B., Dahl-Jensen, D., Bigler, M., Rothlisberger, R., Fischer, H., Goto-Azuma, K., Hansson, M.E., Ruth, U., 2006. A new Greenland ice core chronology for the last glacial termination. Journal of Geophysical Research-Atmospheres 111.

Rinterknecht, V., Jomelli, V., Brunstein, D., Favier, V., Masson-Delmotte, V., Bourles, D., Leanni, L., Schlappy, R., 2014. Unstable ice stream in Greenland during the Younger Dryas cold event. Geology 42, 759-762.

Roberts, D.H., Long, A.J., Schnabel, C., Davies, B.J., Xu, S., Simpson, M.J.R., Huybrechts, P., 2009. Ice sheet extent and early deglacial history of the southwestern sector of the Greenland Ice Sheet. Quaternary Science Reviews 28, 2760-2773.

Roberts, D.H., Long, A.J., Schnabel, C., Freeman, S., Simpson, M.J.R., 2008. The deglacial history of southeast sector of the Greenland Ice Sheet during the Last Glacial Maximum. Quaternary Science Reviews 27, 1505-1516.

Roberts, D.H., Rea, B.R., Lane, T.P., Schnabel, C., Rodes, A., 2013. New constraints on Greenland ice sheet dynamics during the last glacial cycle: Evidence from the Uummannaq ice stream system. J Geophys Res-Earth 118, 519-541.

Sparrenbom, C.J., Bennike, O., Björck, S., Lambeck, K., 2006. Relative sea-level changes since 15000 cal. yr BP in the Nanortalik area, southern Greenland. Journal Of Quaternary Science 21, 29-48.

Steffensen, J.P., Andersen, K.K., Bigler, M., Clausen, H.B., Dahl-Jensen, D., Fischer, H., Goto-Azuma, K., Hansson, M., Johnsen, S.J., Jouzel, J., Masson-Delmotte, V., Popp, T., Rasmussen, S.O., Rothlisberger, R., Ruth, U., Stauffer, B., Siggaard-Andersen, M.L., Sveinbjornsdottir, A.E., Svensson, A., White, J.W.C., 2008. High-resolution 
641

642

643

644

645

646

647

648

649

650

651

652

653

654

655

656

657

658

659

660

661

662

663

664

665

666

667

668

669

670

671

672

673

674

Greenland Ice Core data show abrupt climate change happens in few years. Science 321, 680-684.

Stein, R., Grobe, H., Hubberten, H., Marienfeld, P., Nam, S., 1993. Latest Pleistocene to Holocene Changes in Glaciomarine Sedimentation in Scoresby Sund and Along the Adjacent East Greenland Continental-Margin - Preliminary-Results. Geo-Mar Lett 13, 9-16.

Xu, S., Dougans, A.B., Freeman, S.P.H.T., Schnabel, C., Wilcken, K.M., 2010. Improved Be10 and Al-26-AMS with a 5 MV spectrometer. Nucl Instrum Meth B 268, 736-738.

Young, N., Briner, J., Axford, Y., Csatho, B., Babonis, G.S., Rood, D., Finkel, R., 2011. Response of a marine-terminating Greenland outlet glacier to abrupt coolign 8200 and 9300 years ago. Geophysical Research Letters 38, L24701, doi:24710.21029/22011GL049639.

Young, N.E., Briner, J.P., Rood, D.H., Finkel, R.C., Corbett, L.B., Bierman, P.R., $2013 a$. Age of the Fjord Stade moraines in the Disko Bugt region, western Greenland, and the 9.3 and 8.2 ka cooling events. Quaternary Science Reviews 60, 76-90.

Young, N.E., Schaefer, J.M., Briner, J.P., Goehring, B.M., 2013b. A Be-10 production-rate calibration for the Arctic. Journal of Quaternary Science 28, 515-526.

Figure captions

Figure 1: Overview of North Greenland. Dashed line defines the boundary between the Greenland ice sheet and the independent North Cap (Koch, 1923).

Figure 2: North coast of Greenland with location names mentioned in the text. The inset geomorphological maps show the ${ }^{10}$ Be sample sites on the moraines at A) Henson Bugt, B) Constable Bugt and C) Bliss Bugt (modified from Larsen et al., 2010).

Figure 3: (A) OSL ages of glaciolacustrine sediments (orange) deposited in late glacial epishelf lakes between the shelf-based ice (hatched) and the mountains (Larsen et al., 2010; Möller et al., 2010). Note incomplete bleaching causes the large spread of ages and the youngest age is likely the most reliable. (B) ${ }^{10} \mathrm{Be}$ surface exposure ages of boulders on terminal moraines in Henson Bugt, Constable Bugt and Bliss Bugt (red). Blue stippled line marks the highest marine level on the north coast, c. $40 \mathrm{~m}$ a.s.l. (Möller et al., 2010). 
675 Figure 4: (A) View from the west of the terminal moraine in Henson Bugt. Dashed yellow 676 line indicates the location of the sampled boulders. (B) Setting of boulder and (C) surface of 677 boulder from which sample PEA0719 was collected. (D) Setting of boulder and (E) surface 678 of boulder from which sample PEA0720 was collected. (F) Setting of boulder and (G) surface 679 of boulder from which sample PEA0721 was collected.

680

681 Figure 5: (A) View from the east of the terminal moraine at Constable Bugt. Dashed yellow 682 line follows the crest of main ridge west and east of Sifs River. (B) Boulder on the proximal 683 slope of the western part of the moraine ridge from which sample PEA0618 was collected.

684 Rock drill to the left of the boulder is for scale. Approximate locations of samples PEA0611 685 and PEA0613 are indicated. (C) Close-up of the location of the low and flat boulder surface 686 from which sample PEA0613 was collected. (D) Wide, flat part of the terminal moraine with 687 a small quartz boulder from which sample PEA0621 was collected. (E) Sample PEA0645 688 was collected from a boulder protruding from the till on the eastern part of the moraine ridge, 689 rock drill for scale. (F) Flat cobble $(6 \mathrm{~cm}$ thick) on exposed bedrock on the eastern part of the moraine ridge, collected and processed as sample PEA0647.

691

692 Figure 6: (A) View from the southeast of the western part of the terminal moraine ridge at 693 outer Bliss Bugt. Dashed black line follows the crest of the ridge. (B) View to the south along 694 the ridge. (C) View to the north along the ridge. The dashed line outlines the same part of the 695 ridge as (A). (D) Sample PEA0663 consisted of 20 quartz pebbles collected around the 696 hammer.

697

698 Figure 7: Comparison of the moraine ages with Greenland ice core climate records. The age 699 of the moraines are bracketed by the (A) maximum limiting OSL ages and (B) minimum 700 limiting ${ }^{10} \mathrm{Be}$ ages. Note that the three oldest OSL have not been plotted. (C) $\delta^{15} \mathrm{~N}$ based 701 temperature reconstruction (average of NEEM, GISP2 and NGRIP reconstructions) (Buizert 702 et al., 2014) and (D) $\delta^{18} \mathrm{O}$ record from NGRIP showing an abrupt onset and termination of the 703 Younger Dryas (Steffensen et al., 2008).

705 Figure 8: The terminal moraine in Constable Bugt and the associated reworked organic remains in the up-thrusted glaciolacustrine silt (orange) on the proximal side and marine molluscs in diamict on the distal side of the moraine, used to constrain the age of the moraine. On top of the moraine are the new cosmogenic exposure ages from Constable Bugt. 
709 In the present interpretation the moraine was formed during the Younger Dryas and the up-

710 thrusted sediment on the distal side are related to a younger re-advance 9.6 to 6.3 cal. ka BP.

711 The marine molluscs in the surfical diamict are interpreted as, by solifluction processes,

712 redeposited marine sediments (see text for further discussion).

713

714 Figure 9: Compilation of observed and inferred Younger Dryas ice marginal positions in

715 Greenland (see main text for data source). Underlined place names refer to the marine coring 716 sites mentioned in the text. 
Table 1. Summary of ${ }^{10}$ Be sample information for rock samples from northernmost Greenland.

\begin{tabular}{|c|c|c|c|c|c|c|c|c|c|c|c|c|c|}
\hline Sample ${ }^{a}$ & $\begin{array}{l}\text { Elevation } \\
\text { (m asl) }\end{array}$ & Sample type & Lithology & $\begin{array}{l}\text { Latitude } \\
\left({ }^{\circ} \mathrm{N}\right)\end{array}$ & $\begin{array}{l}\text { Longitude } \\
\left({ }^{\circ} \mathrm{W}\right)\end{array}$ & $\begin{array}{l}\text { Shielding } \\
\text { factor }^{\mathrm{b}}\end{array}$ & $\begin{array}{l}\text { Thickness }{ }^{\mathrm{C}} \\
(\mathrm{cm}) \text { (factor) }\end{array}$ & $\begin{array}{l}\text { Quartz }^{\mathrm{d}} \\
\text { (g) }\end{array}$ & $\begin{array}{c}\text { Be carrier }{ }^{e} \\
\text { (g) }\end{array}$ & $\begin{array}{c}{ }^{10} \mathrm{Be} /{ }^{9} \mathrm{Be} \\
\left(\times 10^{-15}\right)\end{array}$ & $\begin{array}{c}{ }^{10} \mathrm{Be} /{ }^{9} \mathrm{Be} e^{\text {blanks, } \mathrm{h}} \\
\left(\times 10^{-15}\right)\end{array}$ & $\begin{array}{c}{ }^{10} \mathrm{Be} \text { conc. }{ }^{\mathrm{i}} \quad\left(10^{4}\right. \\
\left.\text { at }{ }^{-1} \mathrm{SiO}_{2}\right)\end{array}$ & $\begin{array}{l}{ }^{10} \mathrm{Be} \text { age }{ }^{\mathrm{j}, \mathrm{k}} \\
\text { (ka) }\end{array}$ \\
\hline \multicolumn{14}{|c|}{ Constable Bugt - terminal moraine ridge } \\
\hline PEA 0611 & 130 & pebbles $(n=20)$ & quartz & 83,5877 & 32,2603 & 0,9963 & $2.0(0.9836)$ & 23,303 & $0.1264^{*_{1}}$ & $231.16 \pm 6.16$ & $1.71 \pm 0.70$ & $13.84 \pm 0.47$ & $27.16 \pm 0.93(1.40)$ \\
\hline PEA 0613 & 123 & boulder & meta-sandstone & 83,5879 & 32,2360 & 0,9975 & $3.0(0.9756)$ & 17,200 & $0.2256^{* 2}$ & $73.90 \pm 2.30$ & $6.10 \pm 0.84$ & $5.83 \pm 0.27$ & $11.56 \pm 0.53(0.69)$ \\
\hline PEA 0618 & 86 & boulder & meta-sandstone & 83,5880 & 32,1679 & 0,9986 & $3.8(0.9696)$ & 16,499 & $0.8722^{* 3}$ & $60.51 \pm 2.14$ & $4.50 \pm 0.79$ & $5.94 \pm 0.30$ & $12.35 \pm 0.63(0.79)$ \\
\hline PEA 0621 & 82 & boulder & quartz & 83,5890 & 32,1396 & 0,9993 & $3.5(0.9716)$ & 27,288 & $0.1273^{* 1}$ & $133.65 \pm 4.77$ & $1.71 \pm 0.70$ & $6.84 \pm 0.29$ & $14.27 \pm 0.61(0.82)$ \\
\hline PEA 0645 ${ }^{\#}$ & 112 & boulder & meta-sandstone & 83,5945 & 31,8538 & 0,9996 & $3.5(0.9716)$ & 22,843 & $0.8262^{* 3}$ & $86.35 \pm 4.13$ & $4.50 \pm 0.79$ & $5.93 \pm 0.34$ & $11.94 \pm 0.69(0.83)$ \\
\hline \multirow[t]{2}{*}{ PEA $0647^{\#}$} & 112 & cobble on bedrock & meta-sandstone & 83,5944 & 31,8555 & 0,9996 & $6.0(0.9519)$ & 10,762 & $0.8250^{* 3}$ & $44.45 \pm 1.70$ & $4.50 \pm 0.79$ & $6.14 \pm 0.37$ & $12.60 \pm 0.76(0.90)$ \\
\hline & & & & & & & & & & & \multicolumn{2}{|c|}{ arithmetic mean ( $n=4)$ : } & $12.11 \pm 0.64$ \\
\hline \multicolumn{14}{|c|}{ Henson Bugt - terminal moraine ridge } \\
\hline PEA 0719 & 34 & boulder & quartz & 83,6142 & 32,9454 & 0,9989 & $5.0(0.9597)$ & 22,517 & $0.1272^{*_{1}}$ & $90.61 \pm 3.69$ & $1.71 \pm 0.70$ & $5.58 \pm 0.27$ & $12.47 \pm 0.61(0.77)$ \\
\hline PEA 0720 & 34 & boulder & quartz & 83,6136 & 32,9428 & 0,9988 & $2.0(0.9836)$ & 23,239 & $0.1272^{* 1}$ & $103.40 \pm 4.40$ & $1.71 \pm 0.70$ & $6.19 \pm 0.31$ & $13.50 \pm 0.67(0.85)$ \\
\hline \multirow[t]{2}{*}{ PEA 0721} & 37 & boulder & quartz & 83,6135 & 32,9113 & 0,9986 & $4.0(0.9676)$ & 22,227 & $0.1273^{*_{1}}$ & $90.12 \pm 3.74$ & $1.71 \pm 0.70$ & $5.63 \pm 0.28$ & $12.43 \pm 0.62(0.78)$ \\
\hline & & & & & & & & & & & \multicolumn{2}{|c|}{ arithmetic mean ( $n=3)$ : } & $12.80 \pm 0.77$ \\
\hline \multicolumn{14}{|c|}{ Bliss Bugt - terminal moraine ridge } \\
\hline PEA 0663" & 23 & pebbles $(n=20)$ & quartz & 83,5617 & 29,4832 & 0,9999 & $1.0(0.9918)$ & 18,655 & $0.8309^{* 4}$ & $70.40 \pm 3.03$ & $4.66 \pm 0.90$ & $5.85 \pm 0.33$ & $12.80 \pm 0.72(0.87)$ \\
\hline All moraines & & & & & & & & & & & \multicolumn{2}{|c|}{ arithmetic mean ( $n=8)$ : } & $12.46 \pm 0.73$ \\
\hline
\end{tabular}

"Samples included in Möller et al. (2010) and recalculated in this study.

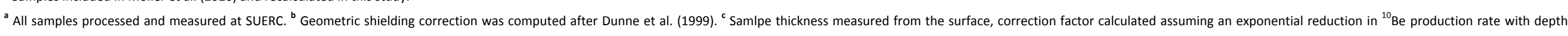

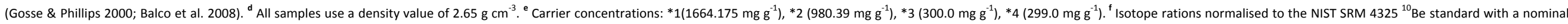

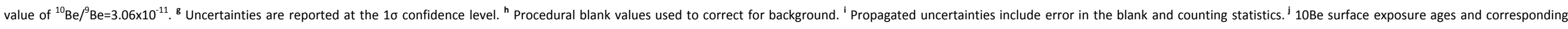

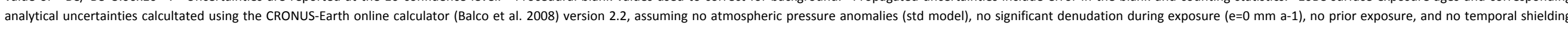

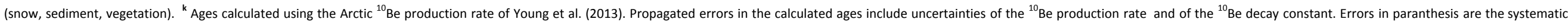
uncertainties. 


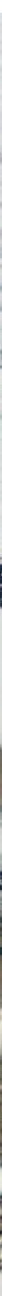

Fig. 2

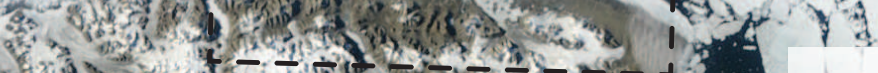


Figure 2

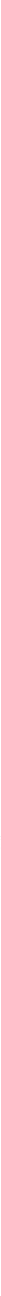


(B)

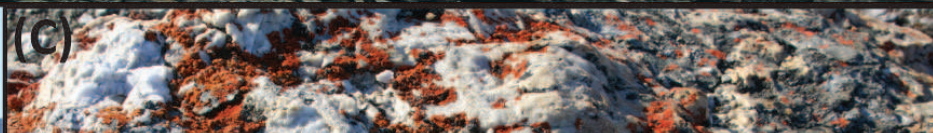

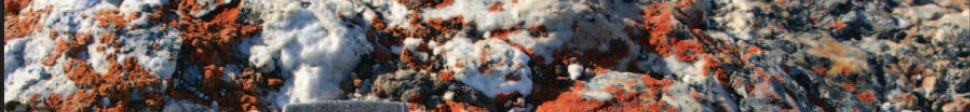

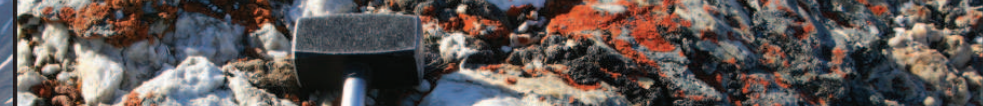

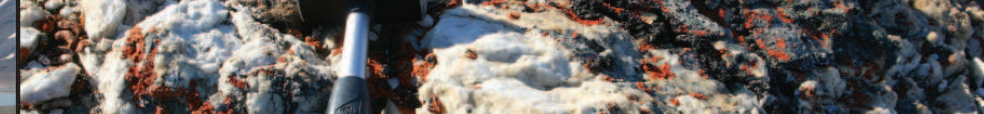

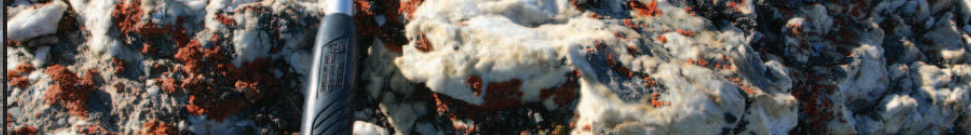

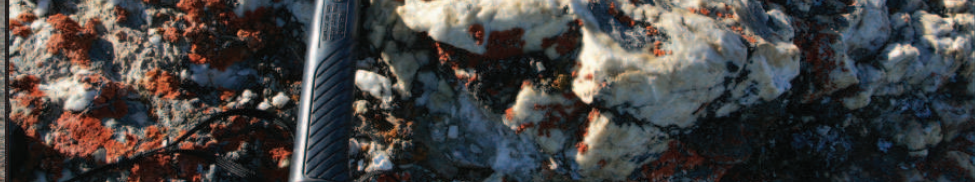

(D)

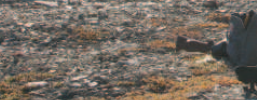

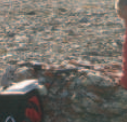

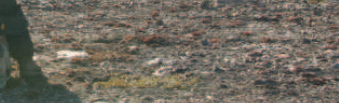

$$
\text { 4. }
$$

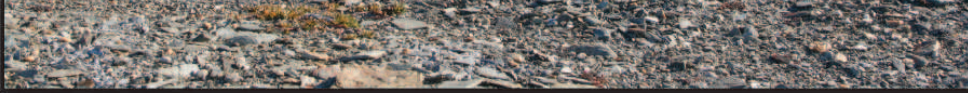

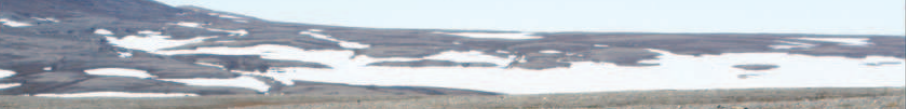

(2) $3.18 \%$ (2)

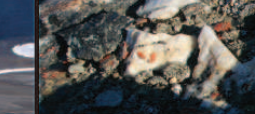

$+2$ $x+2$

3 PEAOZ20

(G)

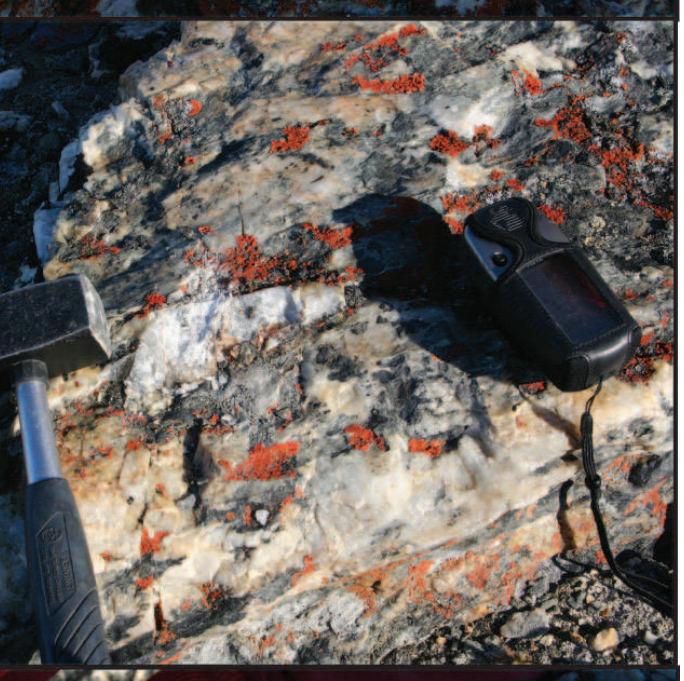

…

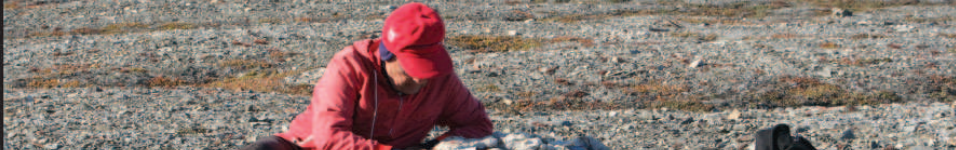

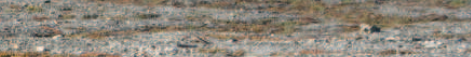

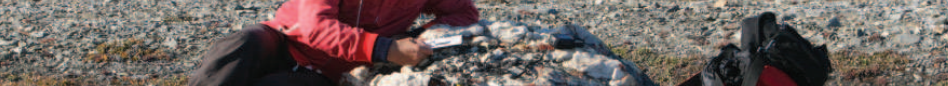
5.

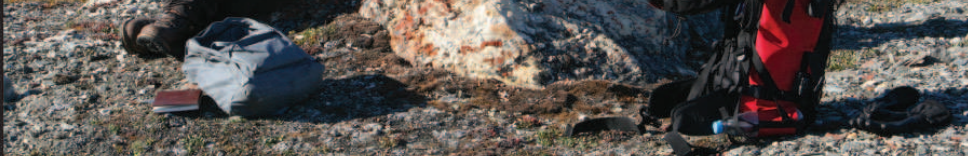

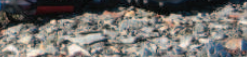

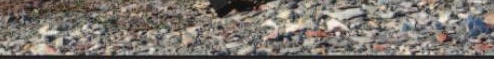

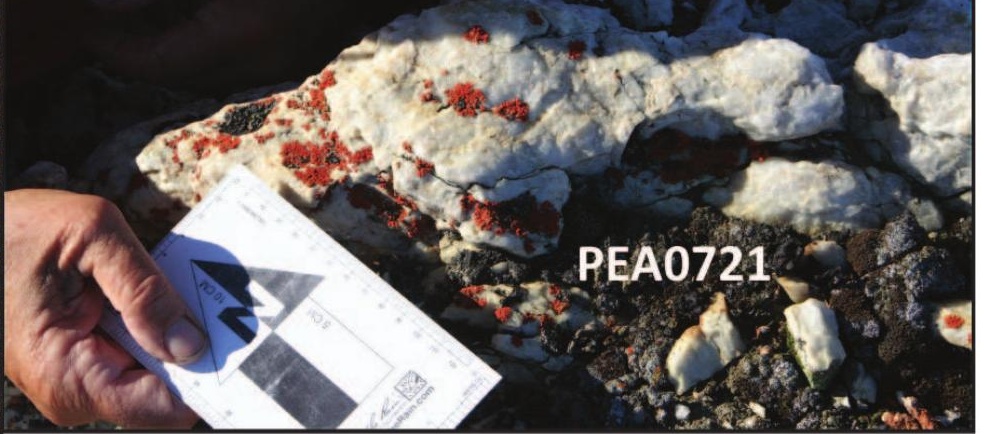


(A)

(B)

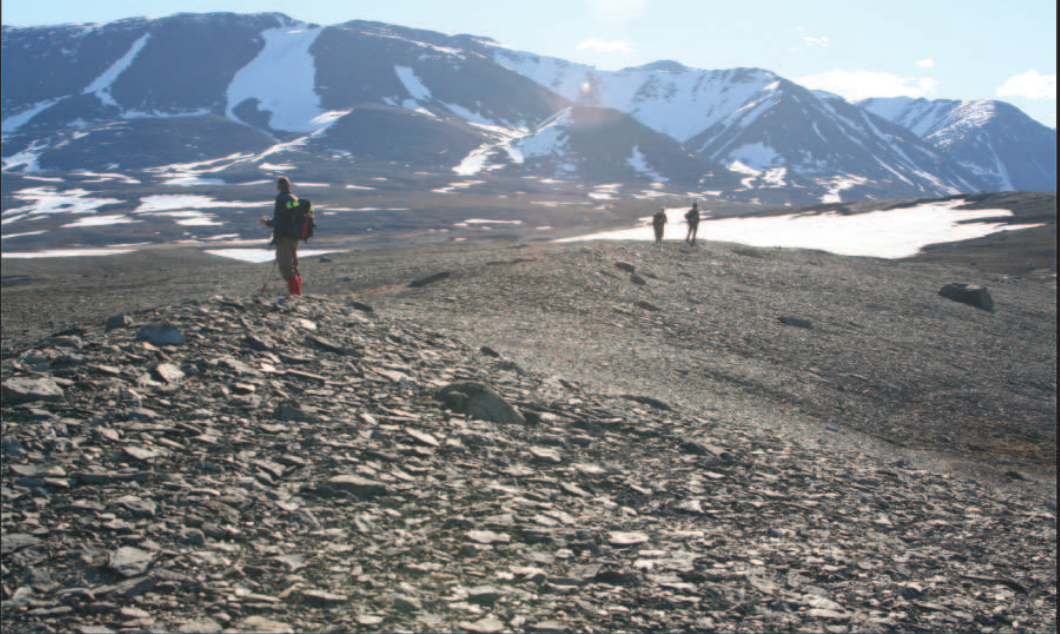

(C)

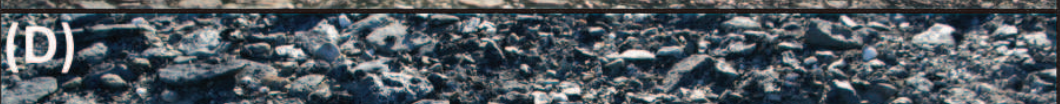

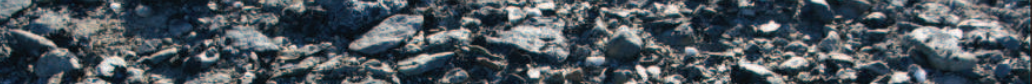

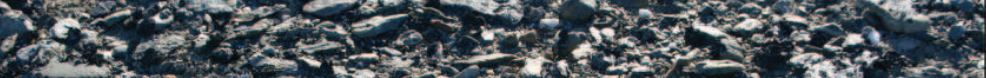

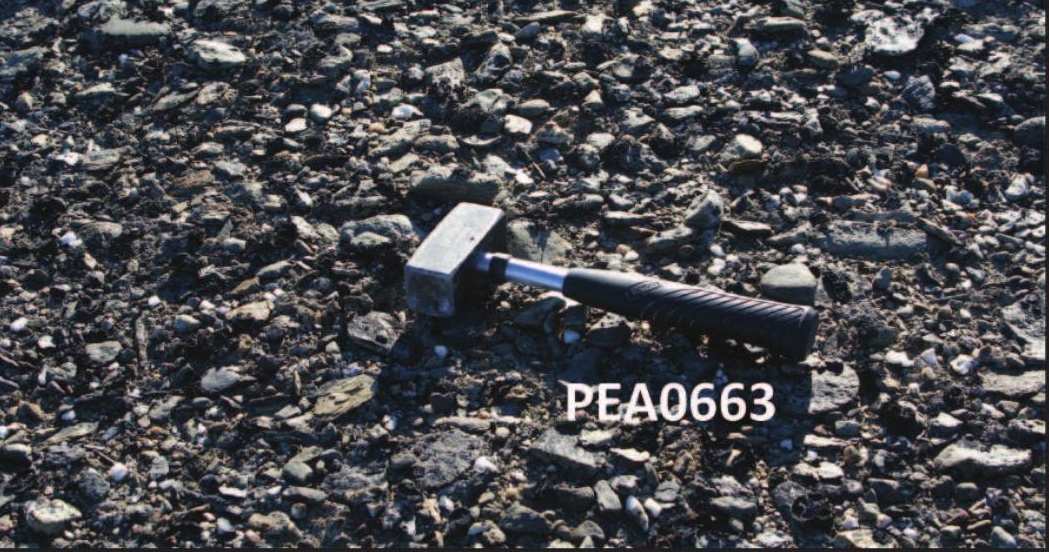

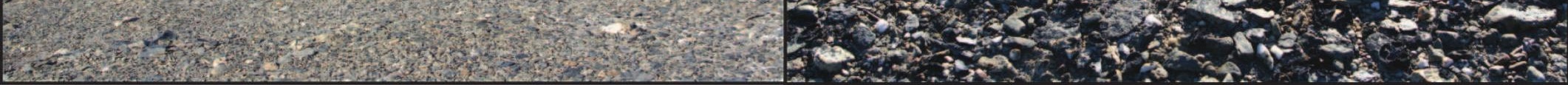


South

$12.1 \pm 0.8 \mathrm{ka}(\mathrm{n}=4)$

North

ca. $100 \mathrm{~m}$
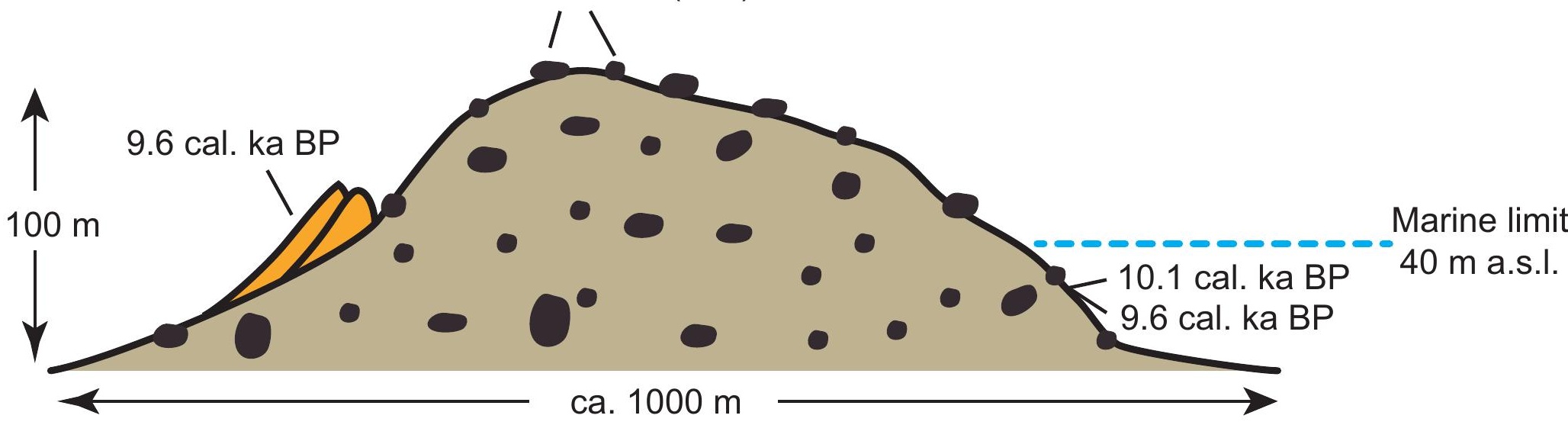

Marine limit

Figure 8 


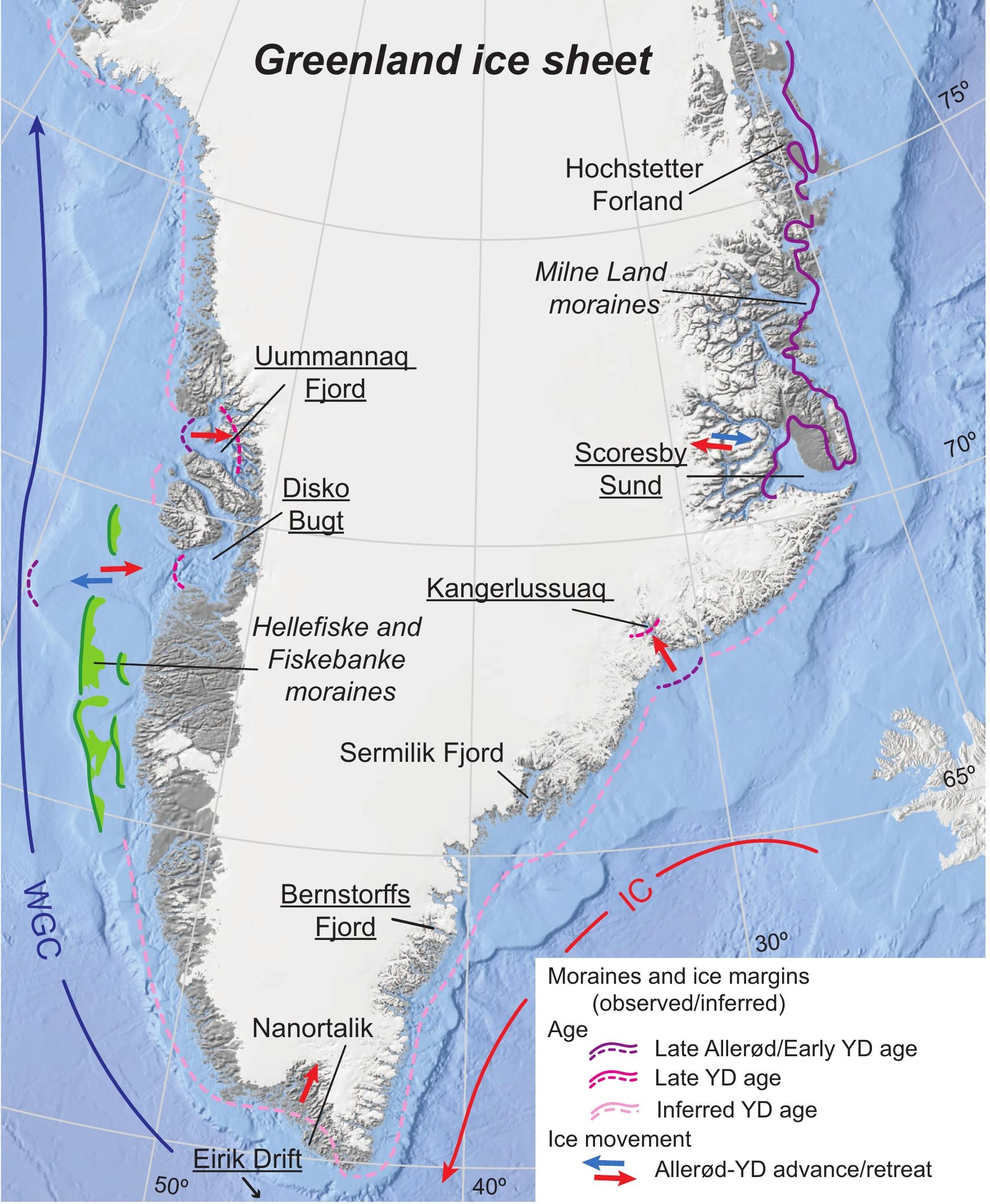

